\title{
Research on Principles and Models of Internet Finance Regulation in
}

\section{China}

\author{
Xi Zhou ${ }^{1, \text { a }}$ \\ ${ }^{1}$ East China University of Science and Technology, Shanghai, China, 200237 \\ ${ }^{\mathrm{a}}$ email
}

Keywords: Internet Finance, Regulation Principles, Regulation Models

\begin{abstract}
In recent years, the rapid rise of internet finance has promoted the development of the finance in China. As a useful complement to the financial system and the exploration of financial innovation, internet finance has put forward new challenges to financial regulation. This paper firstly gives the concept of internet finance, and then analyzes the principles and patterns of internet financial regulation to provide some references for the healthy development of internet finance in China.
\end{abstract}

\section{Concept of Internet Finance}

Internet finance refers to the new financial business model which applies the internet technology and information technology to achieve financial intermediation, payment, investment and information intermediary services by the traditional financial institutions and internet companies. Internet finance is not a simple combination of the internet and the financial industry. It is the new model and new business generated naturally by the technology of security, mobile and other network technology. Internet finance is a combination of traditional financial industry and Internet technology emerging areas. In recent years, China's internet development speed is very fast, which also led to the other industry change in many industries rely on the platform of the Internet, in a certain industry of Internet financial reform the produce is an inevitable trend in the development of the Internet. Internet financial market is conducive to improving the living standards of the masses. However, in the process of the development of internet finance, due to factors such as network technology, often some of the traditional financial fields to participants in the internet financial cause certain risks and losses. As is known to all, the Internet financial threshold is very low, for investors and lenders not very strict review system. In order to make the Internet financial health and stable development, to the financial market brings more convenience. We need to strengthen internet finance supervision in the process of supervision must abide the actual situation of Internet finance. We should grasp certain regulatory principles in order to adapt to the internet financial development trend to realize a better internet finance development.

\section{Regulation Principles of Internet Finance}

Principle of Moderate Regulation. Moderate regulation refers to the effective and limited supervision of financial activities, which is under the premise of respecting the self-regulation of the market. In order to meet the requirements of the appropriate regulatory, regulators should be to respect the law of financial market. Should not be contrary to the market force; try to avoid direct microscopic control. Moderate supervision is a trend of the current financial regulation, Internet banking as a kind of financial innovation. Appropriate regulatory principles have been given more 
significance. We should adopt a tolerant attitude towards the change of the provision and the way of obtaining financial services. Too early and too strict supervision will inhibit the development of Internet banking. Financial regulators to deal with systemic risks remain on high alert, timely intervention and resolve the system risk focus should be settled on the dual characteristics of Internet financial risk. On the one hand, the development of Internet Banking for reducing systemic financial risks has a significant boost, such as the use of Internet platforms and big data technology to slow the information asymmetry. On the other hand, the possibility of Internet Financial amplification system of financial risk cannot be ignored, such as the lower threshold of the moral hazard hidden moral hazard. Only grasp the degree of regulatory can we achieve a good balance between the maintenance of the internet financial innovation vitality and the prevention of systemic risk.

Principle of Serving Economy. Internet finance is an extension of the traditional financial industry. It is a new type of financial model. Therefore, we should clarify the essence of internet finance in the process of development and maintenance of internet finance to ensure that it can be very good for China's real economic construction services. Internet finance is based on the rapid development of the Internet for people to change the way of communication and communication; the reason for the rapid development of internet finance is to fill the gaps in the traditional financial services. Enterprises for financing needs cannot be met through the bank. China's interest rate market process is slow. The low savings rate cannot meet the needs of investors to invest and prompted the expansion of the Internet financial products. The credit problem of the foreign exchange transaction has prompted the emergence of the third party payment, the expansion of the business in order to facilitate and efficiency as the goal, to further promote the development of the third party payment. In internet finance supervision, whether the convenience of the investment and financing services has a significant impact, whether to enhance market efficiency, it should be an important foothold and starting point for the development of regulatory measures. In the supervision of internet finance, we can carry out a certain technical and institutional innovation, but we should take the service finance, service economy construction as the main development principles.

Principle of Information Disclosure. The most prominent problem of the internet finance industry is the information asymmetry. It demonstrates in the false information of debtor, the information concealing of the platform and the illegal information disclosure by regulatory authorities. These human factors caused by information "black hole", resulting in the majority of creditors investment risk laden, natural rating is through revealing creditors note of the credit risk of the obligor to solve hinder the combination of information asymmetry. The full range of data monitoring and data analysis is to control the risk and take the necessary regulatory action in a timely manner. Big data to lay the technical foundation for the development of internet finance, but also for regulators to strengthen the identification of Internet financial risks, monitoring, measurement and control provides a means. Timely access to sufficient data information, regulators understand the basis and the key of the internet finance risk picture. Therefore, the formulation of technical standards for the information monitoring needs based on good practice in the industry, regulators needs and the communication and cooperation to jointly develop monitoring data analysis, index is defined and the statistical scope, frequency, establish and improve the monitoring data, analysis of the mechanism. Networking new financial risks, information monitoring should be flexible enough to maintain a regular assessment of the monitoring effect and continued to improve, to avoid regulatory loopholes, to prevent the emergence of regulatory vacuum. Strengthen information disclosure. We should establish a timely, accurate, relevant and adequate information disclosure system to enhance the financial transparency of the internet. Strengthening information 
disclosure helps to strengthen industry self-regulation. Market subjects use the timely and comparable information on their own business to promote the survival of the fittest and the internet finance business norms.

\section{Regulation Models of Internet Finance}

Classified Regulation. Internet financial development model mainly includes the virtual currency, third party payment, P2P net loan and networking financial institutions. From the regulatory approach, we must implement the classified regulation according to different internet financial bodies. Internet financial services and operational risks are different, and thus differentiated classification of regulatory model in order to strengthen the supervision of targeted, we should implement differentiated classification regulation. In the traditional supervision system based on, strengthen Internet business module specification and system construction, to enhance the bank's own network operation ability, pay attention to the dynamic nature of the Internet business, and from itself characteristics and reasonable combination, strengthen the ability of business revenue, but also learn to use the Internet large data found in depth of its strong growth point, the formation of mutual promotion mechanism for the development of. At the same time, advancing with the times also includes the regulatory authorities, regulatory authorities to enhance their Internet technology to build cannot make supervision technology and disjointed, expand the breadth and depth of supervision, enrich the means of supervision, to ensure the healthy development of internet finance. It will interfere with the normal function of the legal currency. It is likely to affect the authenticity and effectiveness of existing financial statistical data. Virtual account is the core of payment. Although there are restrictions on the people's Bank of China Payment license, regulatory approach still needs to draw on the traditional bank account supervision, inclusive innovation and standardized governance in parallel, technical security and real name recognition is essential. This kind of financing and lending business model has a strong alternative to the traditional commercial banking business. The CBRC (China Banking Regulatory Commission) will shoulder the main regulatory responsibility.

Coordinated Regulation. Internet finance is a combination of the traditional financial industry

and the emerging internet. It has greatly exceeded the business scope of the traditional financial industry, but also to make the rapid innovation of the Internet development model. It not only has the advantages of the Internet and the financial sector, but also inherited the risks of these two industries. The cross industry risk identification, early warning, prevention and control, cannot only use traditional means, in supervision department is not the traditional "Bank + 3" pattern, but also to actively play the role of business, commerce and other departments and between departments to actively cooperation, to deal with the Internet Financial complex risk, in the next period of time to break through the financial separated supervision system, to realize the joint supervision of internet finance. The joint supervision, including Internet financial enterprises their own self-discipline and internal control also includes external intelligence legal departments of criminal investigation supervision, and also includes a cross industry, cross market cross regulation. In this perspective, it needs establishing the horizontal coordination mechanism and coordination mechanism of all sectors. We should also determine the regulatory body, determine the regulatory authorities. In the regulatory body, the formation of a top-down level of the various layers of the perfect coordination agencies, from the central to local joint regulation. In this way, the operation of the enterprise can be better regulated. Internet finance has a larger operating space compared with the traditional market. Only to strengthen coordinated supervision can we maximize the protection of investors' rights and interests. 
Self-regulation. As a bridge and link between the government and the enterprise, the trade association has the function of self-regulation. The establishment of industry associations to improve the supervision of Internet banking is of great significance. There are many problems in the regulation of Internet banking at this stage, and the specific regulatory measures are still in the making. In the regulation of the blank period, the association of self-regulation can play a quasi-regulatory role in a certain extent, to ease the current status of regulatory vacuum. In recent years, has been a part of the Internet financial enterprises set up industry associations. The China Clearing payment Association led by the central bank has an important position in the third party payment regulation. The spontaneous establishment of the industry association by the part of the net loan platform in self-regulation is not enough. Recently, the central bank led the establishment of the Internet Banking Industry Association has been approved by the state council. Such a large number of Internet financial model of the establishment of the association of the Internet banking supervision, development and investor protection are of positive significance. One party to the industry association and can guide members to strengthen self-regulatory cooperation with the regulatory authorities to do a good job of risk prevention. On the other hand, it can promote the communication within the industry, and actively explore innovative models. The regulation of the trade association is a useful supplement to the financial supervision of the internet finance.

\section{Conclusion}

A strong and reasonable regulatory system is beneficial to the development of internet finance in China. Due to the features of the low barrier to entry, convenient operation, cheap transaction cost, the internet finance received high praises by the customers. Also, it brings about the new challenges of regulation for the financial supervision departments. This paper analyzes the principles and patterns of internet finance supervision in China to provide some references for the internet financial regulation.

\section{References}

[1] Pan Yin, Logistics Engineering and Management, Vol. 36(2014) No 4, p.97-98

[2] Zhao Dan, Zhang Hongying, Finance and Accounting Monthly, Vol. 36(2015) No25, p.45-47

[3] Yang Hongqin, Wang Zhaolei, Journal of Shanghai Business School, Vol. 15(2014) No2, p.17-22

[4] Wang Bingbing, Legal System and Society, Vol. 25(2016) No1, p.107-108 